\title{
Seizure After Laminectomy Associated with Pneumocephalus
}

\section{Laminektomi Sonrası Pnömosefali ile İlişkili Nöbet}

\author{
Miraç Ayşen Ünsal Çakmak¹, Şevki Şahin1, Nilgün Çınar¹, Bilal Kelten², Sibel Karşıdağ ${ }^{1}$
}

${ }^{1}$ Maltepe Üniversity Faculty of Medicine, Department of Neurology, İstanbul, Turkey 2Maltepe Üniversitesi Faculty of Medicine, Department of Neurosurgery, İstanbul, Turkey

\section{Seizure After Laminectomy Associated with Pneumocephalus}

Forty-year-old female patient was examined due to the onset of clonic seizures on the left half of the face and left arm starting a day after L4 and L5 subtotal laminectomy. In the computerized tomography, there were numerous air bubbles on the right temporal lobe, fourth ventricle and perimesencephalic region (Figure 1). After observing the intravenous administration of $10 \mathrm{mg}$ diazepam did not suppress the seizures, the status was determined as partial seizure and she was given a loading dose of $20 \mathrm{mg} / \mathrm{kg}$ phenytoin. In the maintenance treatment $300 \mathrm{mg} /$ day phenytoin divided into 3 doses was given. Following bed rest, hydration and close monitoring, the patient was discharged 3 days after neurological stability was achieved. There were no additional neurological symptoms in the 3-month follow-ups. Antiepileptic treatment was planned to continue for another 6 months. Pneumocephalus describes the presence of air pockets in the intracranial cavity. Spinal causes include lumbar puncture, infections, tumors, spinal traumas and surgery (1). Even though there have been multiple reports of symptomatic pneumocephalia following lumbar punction in the literature, seizure is not a common complication of it. The symptoms of pneumoscephalia are generally non-specific and varied and this possible complication should also be kept in mind to prevent severe outcomes.

\section{References}

1. Schirmer CM, Heilman CB, Bhardwaj A. Pneumocephalus: case illustrations and review. Neurocrit Care 2010;13:152-158.

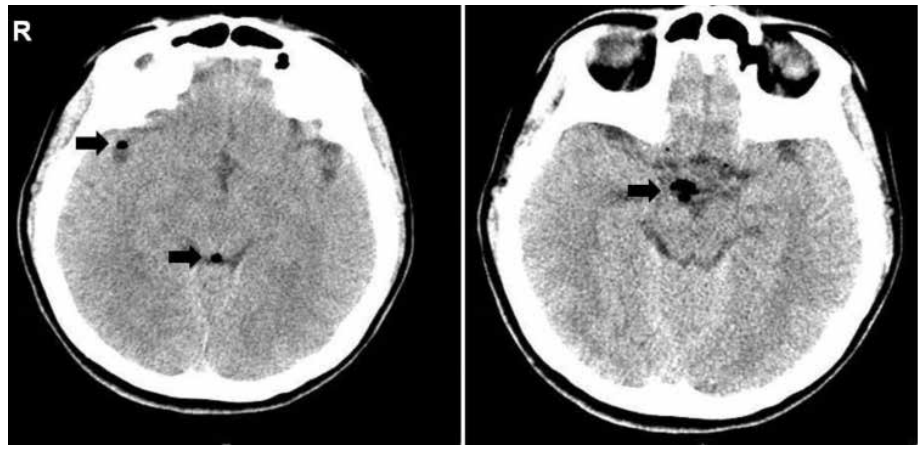

Figure 1. Multiple air bubbles on right temporal lobe, fourth ventricle and perimesencephalic region as seen in axial brain tomography

Address for Correspondence/Yazışma Adresi: Şevki Şahin MD, Maltepe Üniversity Faculty of Medicine, Department of Neurology, İstanbul, Turkey Phone: +90 2163999750 E-mail: drsahin@gmail.com

Received/Geliş Tarihi: 17.06.2014 Accepted/Kabul Tarihi: 29.08.2014 